\title{
VALUE ALLOCATION - CONTRIBUTION AND RISK TO THE RELIABILITY OF FINANCIAL REPORTING
}

\author{
Adela Deaconu, Sorana Crisan, Anuta Buiga
}

\section{Introduction}

The decision-usefulness theory (Staubus, 2008) connects the quality of the financial information disclosed with the right business decisions made by its users, and it is based on the notion that the relevance and reliability of financial reporting is crucial, having important practical implications. Moreover, according to the basic economic theory, it is shown that high financial reporting quality is a natural outcome of private equity monitoring and governance (Beuselinck \& Manigart, 2007). All these firstly imply that the standard setters develop quality accounting standards that are accessible to preparers, understandable and useful for internal (managers) and external users to make their decisions. Secondly, this implies the correct use of accounting standards and regulations and correct estimates. The most important estimation in accounting is due to the use of the fair value concept, a value connected to the market, which is an alternative to historical cost, as the later was the dominant valuation basis up to two decades ago.

The debates on the fair value paradigm are not recent. They had a gradual evolution and became more intense with the awareness of the current financial crisis effects. Fair value can be analyzed theoretically and normatively. In this study we treat the normative approach of fair value, namely accounting and valuation standards. Focusing on the international referential issued by the International Accounting Standards Board (IASB), our research shows that the International Financial Reporting Standards (IFRS) intensify fair value use, peaking with the issue of IFRS 13 Fair value measurement. This FV accounting standard clarifies the definition of fair value, establishes a framework for measurement and requires disclosures about this measurement. Estimations are done in three stages, with a strict preference for market-based measures, fair value being an exit value under idealized conditions (Deaconu \& Buiga, 2010). International Valuation Standards Council (IVSC), the professional association that brings under regulation the activity of assets and businesses valuation at the international level, has its own amendments regarding the concept of fair value. According to IVSC, the definition of fair value is presented in the accounting standards, as the concept is generally consistent with the concept of market value. International Valuation Standard (IVS) 300 entitled Valuations for Financial Reporting presents the view of valuation regulators in what concerns the valuation bases in accounting and fair value estimates.

Starting from these coordinates and the interdependence between valuation practice for financial reporting and a correct estimate of fair value, we established as research question the analysis of the risk inherent to the process of value allocation. This is one stage in the sequence of value estimate techniques for an asset or business and it is implied by the use of two classical valuation approaches, namely the market and the income approaches. These two approaches lead to the estimate of a global value for a group of assets. However, for recognition in the financial statements the value needs to be allocated to each asset. The allocation process is somewhat artificial, at least for a part of the assets in the group, as allocation keys need to be used. Usually, these can be based on value estimates made by valuers or on book values which are not always revaluated according to the requirements of valuation standards. The later solution presented needs to be treated with caution, and this is what we will be focusing on in our present research, especially as we discuss atypical economic contexts. According to (Deaconu \& Buiga, 2010) atypical 
markets refer to assets that are not held for sale or specialized, illiquid markets or non-ordinary transactions, and markets less active specific to emergent economies. The literature shows that the exit price and the premises regarding a perfect market are not applicable to any type of economy (Hitz, 2007; Ronen, 2008; Whittington, 2008).

Focusing on an emergent context, we consider the relevance of historical cost, which is sometimes used in financial reporting, and the relevance of fair values obtained by using a key for value allocation, while considering the case study of the Romanian market. Practically, we adopt an empirical approach in order to investigate the value allocation process in what concerns types of assets under valuation, valuation approaches used, and value allocation keys used by professional valuers. All of these enable us to conclude on the relevance of the value allocation process for financial reporting, and thus the reliability of fair value.

The remainder of the paper is organized as follows: Section 1 explains the research framework, presenting reference to the items important for this research in the literature; Section 2 presents the research design, while describing the research question and the construct of the empirical approach; Section 3 reveals the results of the statistical analysis; and the final section concludes.

\section{Research Framework \\ 1.1 Value Allocation Process}

Without going into details regarding the debate on fair value versus historical cost - debate which is still ongoing - we only wish to mention that fair value is characterized by relevance and accounting neutrality (Casta, Colasse et al., 2001), while historical cost is more objective and reliable as there are no technical issues for its estimation. The parallel presentation of the two concepts underlines the importance of correct fair value estimation as this leads to another imagine of the transactions and activities of a business compared to the traditional system of historical cost, to another economic reality (Ronen, 2008; Rérolle, 2008; Whittington, 2008).

In what concerns the reference to fair value in the accounting and valuation standards, we start with the accounting standards out of which IFRS 13 Fair value measurement clarifies the accounting valuation system and repeals earlier definitions on this subject from various IFRS. IFRS 13 defines the fair value of an asset as the price that would be received to sell an asset in an orderly transaction between market participants at the measurement date. IFRS 13 includes a 'fair value hierarchy' which classifies measurements according to the nature of available input data, namely, in the case of assets: level 1 inputs are quoted prices (unadjusted) in active markets for identical assets that the entity own at the measurement date; level 2 inputs are inputs other than quoted prices included in level 1 that are observable for the asset either directly or indirectly; level 3 inputs are inputs unobservable for the asset. There are additional accounting requirements concerning measurements done using level 3 inputs. A valuation report is adequate if it includes sufficient information on the valuation inputs used (especially level 3 inputs) to enable the reporting entity to correctly categorize assets within this hierarchy (IASB, 2013).

Within the valuation standards, the standard dedicated to fair value measurement, in other terms financial reporting, is IVS 300 Valuations for Financial Reporting. The valuation standard shows that IFRS takes on two models for assets' recognition in the financial statements: a model based on cost, entitled basic accounting approach, and respectively a model based on fair value which represents the alternative accounting approach admissible in certain particular cases. Market values are determined when the fair value approach is applied. According to IVSC (2011), the references to market participants, an orderly transaction, the transaction taking place in the principal or the most advantageous market and to the highest and best use of an asset make it clear that fair value under IFRS is consistent with the concept of market value as defined and discussed in the IVS Framework. According to IVS 300 (IVSC, 2011), when the book value of an element is based on its fair value, and when the value of individual components cannot be reliably determined, the fair value needs to be allocated to each component. Just like accounting standards, IVS recommend that the value allocation process should be described so that the logic behind the allocation can be followed, and the allocation keys should be presented, and their usage justified (IVSC, 2011). In what concerns the allocation keys, IVS 300 shows that the ratio between the cost of the element 
and the cost of the aggregated group could be considered an adequate allocation basis.

The three traditional valuation techniques for assets or businesses are: the market, the income and the cost approach respectively. In relation to the estimation levels mentioned in the accounting standards and in the light of the value allocation process, we could state that the market approach is adequate only for assets or businesses that are frequently subject of market transactions and thus have an active market. It is the only approach that leads to values which could be classified as part of Level 1 in the fair value hierarchy, when they are compared to identical assets. The income approach is applicable when future income/profits generated by the asset can be estimated reliably, the forecast period should be reasonable for these predictions as well as the capitalization/ discount rate used for the forecast period and the profitability of the asset discounted with the risk to obtain the income. Estimates based on the income approach could lead to Level 2 and 3 data in the value hierarchy. The cost approach is generally adequate in the case of specialized and/or new assets, when active markets cannot be identified. Generally, its implementation does not incur allocation issues and will lead to estimates that fall into Level 3 of the fair value hierarchy.

In what concerns the valuation approach chosen, the values obtained could belong to an individual asset or to a group of assets. In the second case the value is obtained globally. The issue of value allocation among the components of the group occurs in the case of market and income approaches, as the global value needs to be differentiated for each asset/ property in order to disclose it separately in the accounts. From the standpoint of valuers the process is entitled value allocation to components. Value allocation is implied by several scopes of the valuation process. The main one, and the subject of our research, is financial reporting (revaluation, goodwill measurement), but in the valuation practice there are also the cases of valuation for tax purposes, loan collaterals, insurance, cases when the tax and financial requirements are different for each component.

As objects of value allocation, the cases mentioned in the international valuation standards IVS (IVSC, 2011) are mainly: land and buildings that form the same property, several buildings (after the initial allocation of land), several pieces of equipment from a production line, capitalized subsequent expenditures, according to IAS 16 Property, Plant and Equipment and IAS 23 Borrowing Costs, which need to be allocated to different fixed assets, the allocation of the acquisition cost for an entire business according to IFRS 3 Business Combination. The first three cases often occur in practice and are sometimes mentioned in the literature which only refers to the difficulties of value allocation between land and buildings. One of the major issues that arise is the possibility that a market for buildings without land does exist, and the second issue is the difficulty to separate the two components (Hendriks, 2005).

The most frequent case of value allocation as his object refers to real estate (land + building), as sometimes the land is not subject to valuation (Matonis \& Derango, 1993). As techniques used by valuation professionals, the literature recommends two deductive approaches from the estimated value for the real estate formed of land and building (Hendriks, 2005): (a) estimating the market value of the land without the building and then deducting this from the carrying amount of the property, and (b) estimating the net replacement cost of the building and then deducting this from the carrying amount of the property. Approach (a) is also recommended by IVS 300 which considers the result a theoretical value' ('notional value') of the building (Kucharska-Stasiak \& Zelazowski, 2006). The literature also presents a third approach (c) for value allocation, namely the use of a proportional ratio established through statistical analyses (Hendriks, 2005). The first two approaches are based on the theory of residual value (Hendriks, 2005). The third approach takes into account the fact that the two elements contribute together to the value created.

In the case of real estate, the net replacement cost is the reconstruction cost or the gross replacement cost decreased by physical impairment and functional inadequacy of the building, sometimes even external (economic) inadequacies (Fishman et al., 2007). The valuation approaches that are applicable to any solution adopted for value allocation are the cost approach, which is mandatory, and respectively one of the other two approaches, namely the income or the market approach (Fisher \& Lentz, 1990; Belfarge, 2001). The argument behind the use of at least two 
approaches is achieving some control keys. Thus, if the value of the building established after the market value of the land was deducted from the result of the income approach or market approach is less than the value of the building established through the cost approach, using only two forms of impairment (physical and functional), then in addition a third form of depreciation (external) will have to be applied in order to obtain the value of the building. If in the previous mentioned case the ratio is vice versa then the value of the building is given by the cost approach, and the difference is considered to be the value of the land.

A second case of value allocation mentioned in the IVS, but insufficiently detailed in what concerns methodology, and very poorly discussed in the literature is (2) the case of several buildings that are subject to different depreciation techniques and thus have to be recognized separately in the financial statements. IVS 300 indicates as a possible alternative the use of a ratio suggesting the contribution of the items to the cost of the whole. In the Romanian practice, the valuation professionals resort to one of the following techniques: (a) a residual alternative that implies the measurement of distinct values for those fixed assets (usually the most important) for which it is possible, and value allocation based on a key in the case of the other assets; this implies that the characteristics and features of these assets are known; the most frequently used approach is the net replacement cost; (b) an alternative that is based on value allocation according to a key applied to the whole value in order to obtain individual values. The allocation key can be determined based on market information transformed into net or gross replacement cost or net or gross book values (with or without deduction of depreciation).

The literature on particular valuation cases such as the cash generation units (Fisher \& Kinnard, 1990; Mard, 2009; Fisher \& Kinnard, 2001). The presents yet another method for value allocation, based on the market values of the components (as often as this is possible). In this case the income is allocated to the components according to the performance ratio of the investment in those components. The residual income is determined for the residual component, either real estate or intangible assets, as the difference between the total income generated by the cash generating unit and the income allocated to the other components. Afterwards, the residual income is capitalized by an adequate rate in order to obtain the value of the residual component.

The literature also mentions that the process of value allocation in general implies thorough professional knowledge from the valuer and at the same time the responsibility to know and apply national valuation standards on this subject (Harper, 2008). Likewise, other regulatory bodies in the field of valuation (for example the American regulatory body) include in their standards requirements for their members to provide in the value allocation process accuracy and an objective opinion regarding the value of the components. The importance of the subject leads to preliminary discussions in the valuation practice between the valuer and the auditor of financial statements regarding a consensus about the valuation approaches and residual techniques. Professional reasoning is extremely important in the value allocation process as long as there is no intensive practice or line of reasoning that can be followed.

\subsection{Emergent Markets}

For emergent markets in particular there is a multi-tiered valuation practice and a very limited availability of investment transactional evidence, with effects on the accuracy of valuations (Kucharska-Stasiak \& Zelazowski, 2006; Mansfield \& Royston, 2007). Although investors require a common denominator such as property indices for assets valuation and income prediction, there are differences regarding public information availability in a unitary framework in comparison to developed countries. When it does exist, the information is not consistent and complete among the valuators in a low information environment such as the emergent one. The history of the sale and rent transactions is recorded by real estate agents, such as real estate brokers and appraisal practitioners who assemble their personal databases, a central database development being at an incipient stage (Cohen \& Galiniene, 2013). Thus, the market approach is not applicable for all types of assets and at every given time, as Levels 1 and 2 of the value hierarchy (mark-to-market model) cannot be obtained.

When the markets are volatile, such as emergent markets or are affected by economic crises, the main approach sustainable on the 
long run is based on income (Baumgarten, 1978; Fanning et al., 2011; Hrdý \& Šimek, 2012). However, even this approach poses the issue of obtaining the market information necessary for the assessment. Likewise, professional reasoning becomes very important when the markets are unbalanced (including emergent markets), and valuers need to be able to distinguish between information that will enable a measurement based on efficient, balanced and stabile data (Mard, 2009). This approach will lead in general to Level 2 and 3 values in the fair value hierarchy. Thus, if the specific market of an asset does not exist or is not active, efficient, then the fair value will not be established directly, based on information that is generally described as objective, but rather by using valuation models based on several subjective estimates, less verifiable.

Regarding level 3 of measurement (markto-model) which concerns the income or cost approach, the risk of value allocation is connected to the income approach. In order to mitigate this risk, the accuracy of allocation needs to be taken into consideration as well as the way in which the valuers disclose their undertakings. The literature issued after the start of the financial crisis insists on the need for disclosures to provide some details concerning the construct of fair value and its influence over the result of the period (Hitz, 2007; Gottdiener, 2008). For example, in the case of the income approach one needs to estimate: the useful life of the asset, its residual value, the cash inflows the asset will generate over time and the discount rate. Estimates themselves are subjective. In addition, intentional distortion of certain metrics can occur. Thus, the valuation model implies an inherent risk, plus another risk connected to intentional manipulation of information (Gélard, 2002).

We could say that the Romanian context has been characterized by inflation for the past two decades, with a high risk for the historical cost to move further away from reality. This is also due to the fact that some revaluations were not always conducted according to the requirements of the valuation profession. Other difficulties concerning fair value estimates are connected to the income approach which has been difficult to apply given the possibility of forecasts to be invalidated by the ever-changing economic context, and respectively to the market approach which has been sometimes impossible to apply because of the lack of transactions, as shown above. Statistical techniques for value allocation based on the history of previous transactions cannot be applied on such a market as a result of the lack of transparency in what concerns the specific evolution of the market for different types of assets.

If we were to present the evolution of the Romanian real estate market - which is the subject of our analysis - in the last decade there are three different periods. First there is the period between 2002 and 2007 when prices significantly grew including because of the fact that Romania was preparing to adhere to the European Union (the adherence took place in 2007). Then the prices plunged as a result of the economic crisis. After three years of powerful decline, 2008-2010, in the last part of 2010 the recovery of the real estate market started, with positive signals for 2011. The slight recovery of the market is suggested by the growing number of transactions for all types of real estate, even with increasing prices. In what concerns our analysis period, the year 2013 , we could state that the market is relatively stable, and the market approach in valuation can be applied, even if not for all types of assets.

\section{Research Design}

\subsection{Research Question}

Good valuations depend upon proper analysis and weighing of the factual matrix in any situation. These are guided by the professional standards. Then, certain characteristics of valuation practice are determined by the context of the asset and the market, along with the professional reasoning of the valuator. In our paper, starting from the requirements in the standards, we verify the practical approaches to value allocation, a suggestive theme to the reliability of valuations for financial reporting. The process of value allocation is an influential factor of a reliable and relevant value, considering that the use of an inadequate allocation key and/or an incorrect implementation of the keys could lead to distorted values of the components. The consequences can be found in accounting recognition of an asset that is the subject of a different efficiency analysis of investments or they are tax related with impact on the value of property tax and profit tax, in the case of assets subject to depreciation.

For atypical/emergent markets the issue of value allocation is all the more important 
as market information is insufficient, few transactions occur, and book values lose their significance due to monetary depreciation and hard to predict volatile markets of certain assets. Thus, the valuation of each type of asset to the market could not be possible, and so allocation keys need to be used. The value allocation technique that uses a ratio established through statistical analyses is to be used with caution because such contexts confront with the lack of a reliable database which would provide historical trends statistically validated. The compromise solution would be to use book values. On the other hand book values cannot reflect the state and viewpoint of the market, correlated with the best possible use identified for the assets under valuation. Moreover, the use of allocation keys based on accounting information could lead to distorted results, especially if the book values have been distorted by old revaluations that were inaccurately made, or due to different depreciation approaches used for the assets taken into account.

The research question needs to be correlated with the Romanian context. Firstly, we verify the degree to which fair value is used in the Romanian context, thus the frequency of valuations for financial reporting, and from here the value allocation. In the Romanian accounting regulations, issued by the public authority, the Ministry of Finance (OMPF no 3055 from 2009) fair value is explicitly mentioned for revaluation of tangible assets and for financial instruments. Other references to fair value are implicit, such as the value determined for the non-cash increase of capital that has to be established as a result of valuation. Considering the valuation approaches permitted by the Romanian accounting legislation, the market and valuation professionals which should determine fair value are mentioned in the alternative valuation rules section. Also, other valuation methods besides market comparison are accepted if there is not enough market information. The regulations described are applicable to all companies and coexist with the regulation that envisages the implementation of IFRS by listed companies for their consolidated accounts, starting with January 2007 (OMPF no 1121 from 2006). Because the use of financial instruments has an extremely slow evolution in Romania, we can conclude that tangible fixed assets revaluation was the most common case of fair value estimation explicitly stipulated in the Romanian regulations. Thus, we will focus on a survey answers provided by the valuators for this objective of valuation for financial reporting, and we will further discuss the premises for revaluation operations in the Romanian companies.

A specific importance has been given in Romania to revaluation, and the approach we are going to describe can also be found in other countries, as the value established has fiscal connotations. Local taxes on company real estate are determined as a percentage of the book value of those assets, which may or may not be revaluated. The effects are obvious, both for the financial performance and profitability of the company reflected in the financial statements after the revaluation, and for the income of public authorities.

The legal permissive nature of revaluations manifested for all fixed assets such as plant, properties and equipment by the gradual issue of certain normative acts. These acts had the objective to adapt the elements in the financial statements of companies to the economic environment by the update of historical cost and the unimpaired value of assets. We are talking about Government Decision (GD) no 945/1990, GD no 266/1992, GD no 500/1994, GD no $983 / 1998$ amended and restated by GD no. 95/1999. These regulations were applicable either to all fixed assets or only to plants and properties. The regulations had either a compulsory nature (for the companies in which the state was the major shareholder) or an optional nature (as the case of GD no. 983/1998). All of these revaluations used the index updating method and were classified in the literature as administrative revaluations, as they have been subject to criticism because of the method in which the indexes are selected and because only one method of valuation is used. They did not lead to true market values, but they did represent a first step toward market approach in valuation. The process of value update was the responsibility of a committee formed by company employees. GD no $403 / 2000$ leaves fixed assets revaluation up to the companies. The difference in comparison to previous revaluations is that companies which conducted revaluations (in the circumstances described by the GD regarding the economic environment, measured using the inflation rate) are able to use other valuation methods 
considered adequate, and can also resort to an external professional valuator. Concluding, at this date, we can talk about fair value in the true sense of the concept, if the companies have resorted to authorized valuators that applied dedicated valuation approaches, and did not just update the value by the inflation rate. The consequence for our study is that book values must be considered with precaution in general on the valuation market, as there is the possibility they contain revaluations that have not been made according to the requirements of valuation standards.

In this context our research focuses on the way in which value allocation is made. Thus our research question is: to what extent do valuators from emergent markets apply in their valuation reports value allocation to components, what are the valuation approaches most frequently used, and what are the allocation keys most often used. The use of the market approach would reduce the risk of the model triggered by the other two approaches, the income and the cost approach. In what concerns the allocation keys, we want to determine if the valuers base their opinion on keys that do not lead to distortions in the financial position which affect the decisions made by stakeholders of financial situations.

\subsection{Instrument, Sample and Statistical Tests}

Considering the objective of our research, the empirics of the study try to capture the perceptions of Romanian valuers as producers of fair value for financial reporting purposes. By using a survey we test the experience of valuators and their approaches in more complex situations that imply the use of professional reasoning, particularly if they are familiar with and apply several methods of value allocation between components of fixed assets with different accounting treatments.
In this respect, we designed a selfconstructed instrument, of semi-structured type, addressed to the Romanian valuators community. The survey contains in the first part a series of support questions that are designed to gather information on the quality and experience of the respondents. These questions focus on the qualifications and experience with valuations of the respondents, their affiliation to professional bodies, and the size of the businesses they valuated, which gives insight on the experience they have with more complex cases. The instrument was also designed to investigate the elements prior to the value allocation process which relate to the nature of the asset under valuation and the applied methodology, and respectively, to deepen the practical process of value allocation.

Table 1 shortly presents the interview instrument, which is detailed in Appendix 1.

The survey instrument was conducted online from February 2013 to March 2013, on a web platform which was available for four weeks, while the proposed investigation was made public on the official website of the National Association of Romanian Valuers (ANEVAR). ANEVAR also made the investigation public through its regional centers, by e-mailing the message to its members.

The population studied is represented by valuers, current members of ANEVAR, which is also a member of the international body IVSC and the European forum TEGoVA. We addressed the members who are enlisted with an e-mail account in the database of the association, out of the total number of 4,718 existing members. The number of active members that could have answered is lower, although we do not hold public information regarding the number of inactive members, which we can only estimate to $3,200-3,500$. This is the reason why we did not use samples,

\section{Tab. 1: The survey instrument for valuers}

\begin{tabular}{l|l}
\multicolumn{1}{c|}{ Parts of the instrument } & Number and type of items \\
\hline $\begin{array}{l}\text { Part 1 Characteristics of the activity of valuers } \\
\text { practical experience as seniority and qualification, respectively size and } \\
\text { nature of the valuated assets and type of valuation approaches }\end{array}$ & $\begin{array}{l}3 \text { open-ended questions } \\
3 \text { categorical questions }\end{array}$ \\
\hline $\begin{array}{l}\text { Part 2 Perceptions on the process of value allocation } \\
\text { regarding means of value allocation and keys for value allocation }\end{array}$ & $\begin{array}{l}\text { 3 open-ended questions } \\
1 \text { categorical question }\end{array}$ \\
\hline
\end{tabular}




\section{Ekonomika a management}

but the whole database of ANEVAR. The initial volume of the sample summed up to 377 valuers. The surveys not filled out to a minimum of $90 \%$ were eliminated from the analysis. And thus we reached the final sample of 250 subjects.

In what concerns statistical test, we used descriptive statistics (frequencies), and the T-test, One-Sample version. The T-test is usually used for the analysis of a sample out of a defined population in order to determine if there are significant differences between the different analyzed categories.

\section{Analysis Results}

\subsection{Descriptive Statistics}

The characteristics of the valuers' activity are presented below. In what concerns qualification we noticed an overspecialization regarding real estate and plant \& Equipment. As a result, we reduced the weights of these specializations also in order to have a structure almost similar to the structure of the population. In what concerns the frequency of valuations according to the nature of the asset, we compared the obtained values to the binomials formed by the categories in order to establish the connection between the values.

\section{Tab. 2: Characteristics of the valuers' activity}

\begin{tabular}{|c|c|c|c|c|c|}
\hline \multirow[t]{2}{*}{$\begin{array}{l}\text { Characteristics } \\
\text { of valuers }\end{array}$} & $\begin{array}{l}\text { Professional experience (years) } \\
\text { Less than } 2 \text { years } \\
\text { Between } 2-5 \text { years } \\
\text { Over } 5 \text { years }\end{array}$ & \multicolumn{4}{|c|}{$\begin{array}{l}10 \% \\
18 \% \\
72 \%\end{array}$} \\
\hline & $\begin{array}{l}\text { Qualification }^{* *} \\
\text { Real estate } \\
\text { Business, intangibles, goodwill } \\
\text { Plant \& equipment } \\
\text { Financial instruments } \\
\end{array}$ & \multicolumn{4}{|c|}{$\begin{array}{c}78 \% \\
55 \% \\
30 \% \\
0 \% \\
\end{array}$} \\
\hline \multirow[t]{2}{*}{$\begin{array}{l}\text { Magnitude } \\
\text { of valuations } \\
\text { for financial } \\
\text { reporting } \\
\text { purposes }\end{array}$} & $\begin{array}{l}\text { Weight in the total volume of } \\
\text { activities undertaken* } \\
\text { Less } 10 \% \\
\text { Between } 10 \text { and } 25 \% \\
\text { Between } 25 \text { and } 40 \% \\
\text { Over } 40 \%\end{array}$ & \multicolumn{4}{|c|}{$\begin{array}{l}24 \% \\
35 \% \\
20 \% \\
21 \%\end{array}$} \\
\hline & $\begin{array}{l}\text { Frequency of valuations } \\
\text { for companies with patrimony } \\
\text { of different sizes } \\
\text { Consistent patrimony } \\
\text { Medium patrimony } \\
\text { Low patrimony } \\
\text { Insignificant patrimony }\end{array}$ & $\begin{array}{r}- \\
12 \% \\
10 \% \\
12 \% \\
\end{array}$ & $\begin{array}{c}\text { Medium } \\
\\
47 \% \\
- \\
22 \% \\
25 \% \\
\end{array}$ & $\begin{array}{c}47 \% \\
46 \% \\
- \\
31 \% \\
\end{array}$ & $\begin{array}{c}46 \% \\
43 \% \\
45 \% \\
- \\
\end{array}$ \\
\hline \multirow{2}{*}{$\begin{array}{l}\text { Characteristics } \\
\text { of the valuations } \\
\text { according to } \\
\text { the nature of } \\
\text { the assets and } \\
\text { the valuation } \\
\text { approaches }\end{array}$} & $\begin{array}{l}\text { Categories of assets } \\
\text { Land } \\
\text { Buildings } \\
\text { Plant \& equipment }\end{array}$ & $\begin{array}{l}\text { Land } \\
\qquad \begin{array}{l}- \\
14 \% \\
39 \%\end{array}\end{array}$ & $\mathrm{Bu}$ & & $\begin{array}{c}\text { Plant \& } \\
\text { equipment } \\
17 \% \\
9 \% \\
-\end{array}$ \\
\hline & $\begin{array}{l}\text { Valuation approaches* } \\
\text { Land } \\
\text { Buildings } \\
\text { Plant \& equipment }\end{array}$ & $\begin{array}{c}\text { Market } \\
93 \% \\
27 \% \\
37 \%\end{array}$ & \multicolumn{2}{|c|}{$\begin{array}{c}\text { Income } \\
6 \% \\
34 \% \\
8 \%\end{array}$} & $\begin{array}{l}\text { Cost } \\
1 \% \\
39 \% \\
55 \%\end{array}$ \\
\hline
\end{tabular}

Notes: *We used the percentage without taking into consideration the non-answers; **The gross sample became a weighted sample by relating it to the population, in order to extrapolate the distribution observed for the whole population; ${ }^{* * *}$ The differences in frequency between the categories with bolded values are statistically significant, for a significance level (threshold) of $95 \%$. 
In what concerns the years of experience held by the valuers, compared to the seniority of the valuation profession in Romania, which is institutionalized through ANEVAR that was incorporated 20 years ago, we consider that the obtained distribution is relevant for the valuers in Romania. The observations in Table 2 also indicate that the valuers are multispecialized, and the dominant specialization is real estate. At the same time a considerable part of the sample is specialized (also) in business, intangible and goodwill valuations, and more than a third are (also) specialized in plant \& equipment. These findings confirm the competencies of professionals considering the value allocation process that implies knowledge of several disciplines.

Moreover, we note that these professionals are familiarized with financial reporting valuation, as long as over half of the sample conducts this type of valuation between $10 \%$ and $40 \%$ of their activity. A further argument for the validation of the sample is the number of valuations for financial reporting purposes compared to the size of the patrimony valuated. Valuers conduct relatively often complex valuations, for companies with consistent patrimony, although the most frequent valuations are conducted for companies with low patrimony, and the frequency of the valuations decreases as the size of the patrimony increases.

The frequency of valuation reports conducted for financial reporting purposes follows the succeeding general order: buildings, land and plant \& equipment. In comparison to land valuations, buildings are more often the subject of valuations in $65 \%$ of the cases, while the opposite situation occurs only in $14 \%$ of the cases. After applying the One-sample T-test we observed that $51 \%$ of the valuers consider buildings are more often subject of valuation compared to plant \& equipment while $9 \%$ consider the opposite situation. Furthermore, with respect to valuation approached applied, while $93 \%$ use the market approach for land valuations, for buildings the market, income and cost approaches are equally used, and for plant $\&$ equipment the cost and market approaches are mainly used. What is useful for our further analysis is that valuers have mostly applied the market and income approaches, which are considered global approaches. This shows, theoretically, that value allocation was applied in the valuation reports of all the three types of fixed assets, thus the premise for further analysis exists.

\subsection{The Analysis of the Valuers' Perceptions Regarding the Value Allocation Process}

Our findings confirm that value allocation as a stage of the valuation process for financial reporting purposes is correctly applied in the Romanian practice. Thus, $98 \%$ of the valuers state that they deliver the value of each component, after using one of the allocation options. Out of these, $64 \%$ conduct the valuation as a whole and afterwards they allocate the value to the components, while $34 \%$ estimate the value directly for each component, and an insignificant percentage state they leave the value allocation at the will of the beneficiary, without getting involved in this process. We conclude that Romanian valuers apply valuation standards as they resort to value allocation if this is needed, despite the difficulties triggered by the atypical market.

In what concerns value allocation between land and buildings, $78 \%$ for the answers described the preference for deducting the estimated market value of the land without the building from the estimated value for the property. Only $17 \%$ of the respondents confirmed they use the second alternative i.e. deducting the estimated net replacement cost of the building from the total estimated value of the property. What is interesting is that $5 \%$ of the valuers use other alternatives for value allocation, depending on the property rights for the land, the best possible use of the asset compared to its current use, or the test of enclosing the residual value of the building into the estimated net replacement cost. We note the focus on market values and market approach (correlated with the answers regarding the approach mostly used, which in the case of land valuations is the market approach), which is more reliable than the cost approach, and also the advanced technical knowledge of valuers that resort to allocation techniques.

In what concerns value allocation between different types of buildings, $69 \%$ of the respondents with an opinion on this subject state they deduct the value of the buildings that was possible to be estimated separately by using a classical valuation approach, and for the remaining buildings they allocate the rest of the value by using allocation keys. A quarter 


\section{Ekonomika a management}

of these respondents allocate value by using directly an allocation key. Very few, around 3\%, use other methods of allocation. We observe that more than half of the sample tries to avoid arbitrary allocation by using keys, as they try to estimate the value through the approaches required in the valuation standards.
We tried to identify the allocation keys most frequently used by valuers, and based on the frequencies (Tab. 3) we found that the allocation keys' hierarchy is: net replacement cost (NRC), gross replacement cost (GRC), net book value (NBV), and gross book value (GBV).

\section{Tab. 3: Value allocation keys used by valuers}

\begin{tabular}{l|c|c|c|c} 
& GBV & NBV & NRC & GRC \\
\hline GBV & - & $25 \%$ & $\mathbf{2 7 \% ^ { * }}$ & $\mathbf{3 5 \%}$ \\
\hline NBV & $21 \%$ & - & $24 \%$ & $\mathbf{3 5 \%}$ \\
\hline NRC & $14 \%$ & $18 \%$ & - & $\mathbf{3 6 \%}$ \\
\hline GRC & $12 \%$ & $13 \%$ & $13 \%$ & - \\
\hline
\end{tabular}

Note: *The differences in frequency between the categories with bolded values are statistically significant, for a significance level (threshold) of $95 \%$.

The result of the T-test (Tab. 4) shows that in the case of value allocation between buildings, there is no clear difference between the use of GBV and NBV, and respectively between GRC and NBV. Instead the findings show a clear difference between the use of GRC compared to GBV. Moreover, NRC is more often used than the other three allocation keys we proposed. If we conduct the analysis of groups of keys, the first one being values estimated by the valuers and the second group representing the book values (net or gross) then the replacement cost (net or gross) turns out to be significantly more often used than book values.

\section{Tab. 4: Differences in allocation keys usage}

\begin{tabular}{l|c|c|c}
\multirow{2}{*}{\multicolumn{1}{c|}{ Compared allocation keys }} & \multicolumn{3}{c}{ One-Sample Test } \\
\cline { 2 - 4 } & $\boldsymbol{t}$ & $\boldsymbol{D f}$ & Sig. (2-tailed) \\
\hline GBV-NBV & 0.895 & 115 & 0.373 \\
\hline GRC-GBV & 3.375 & 101 & 0.001 \\
\hline NRC-GBV & 5.903 & 119 & 0.000 \\
\hline GRC-NBV & 1.584 & 106 & 0.116 \\
\hline NRC-NBV & 5.563 & 122 & 0.000 \\
\hline NRC-GBV & 5.869 & 122 & 0.000 \\
\hline Groups of keys compared & 5.653 & 95 & 0.000 \\
\hline NRC-GRC versus NBV-GBV
\end{tabular}

Notes: Test value $=0.5$; the values are statistically significant for a significance level (threshold) of $95 \%$. 


\section{Conclusions}

Our study pleads in favor of reliable fair value estimates that enable accurate decision making for stakeholders of the financial reporting market. The paper is particularized to emergent contexts, having the Romanian market and fixed assets as case study, and it shows how fair value estimation is critical and implies risks on such an atypical market. The research focuses on the process of value allocation between the elements of a group of assets when a valuation approach that leads to a global value is applied, namely the income and market approaches. The value allocation process is described with reference to accounting and valuation standards and to the literature. We show how this process can lead to a significant level of subjectivity regarding fair value accounting. We also confirm the importance of applying correctly the valuation methodology in what concerns the nature of the property and the available market information, alongside the choice of allocation keys.

Our analysis shows that the most suited allocation key for groups of assets formed of fixed assets (land, buildings and plant \& equipment) should be based on the net or gross replacement cost, thus on values estimated by the valuer and not on book values, in order to avoid results distorted by historical cost. In what concerns the revaluation of fixed assets, we showed that if previous revaluations would have been accurately conducted then net or gross book values could have been considered allocation keys. However, despite the acceptance of the public authority that issues accounting regulations and the intervention of professionals in valuation and their methodology, the history of revaluations for the past two decades in this country shows the risk of revaluations conducted in the alternative solution permitted, namely values updated by the inflation rate or valuations conducted by individuals unauthorized by the national professional association ANEVAR. In this case the revaluated book values cannot be considered relevant for the evolution of the markets specific to different fixed assets.

The empirics of our study show a consistent expertise of Romanian valuators that prove to be familiar with their own value allocation methodology and the alternatives for allocation keys, as they sometimes apply other keys than the replacement cost, keys that are market based. We also present that allocation keys usage comes in second place, as valuators first try to estimate market values for each component of the group of assets, without allocating from the very beginning the value estimated for the whole group to each component based on allocation keys. The majority of valuers allocate the value to each component from the start, as opposed to the alternative of estimating the value of the whole group and then allocating the value to components with the inherent risks. Furthermore, the most often used alternative for allocation implies the deduction of those values that have been estimated by using the market approach and not those values estimated thorough the cost or income approach (the latest was less used for the fixed assets under analysis). Other findings confirm the main usage of replacement cost, gross or net, to the detriment of book values, a very important aspect for an emergent market, all the more as revaluation in Romania does not guarantee the usage of dedicated valuation methods. These results are all the more important as land and buildings were the majority of fixed assets valuated, with the highest values as a result of the real estate bubble prior to the financial crisis, and with an essential role in the activity of the companies, thus being highly considered for accurate and reliable valuations.

All of these findings lead us to the conclusion that fair value estimates for financial reporting purposes, in the Romanian companies, in the case of global value allocation to the components of a group of assets (the case most exposed to the subjectivity of the valuator), is reliable at this date. The inherent risks of this valuation process are acknowledged by the Romanian professionals, and avoided if market information exists, specific to each type of asset from the group. The limits of our study are related mostly to the shortcomings of the survey methodology. In this case we refer to the risk of the quality and authenticity of the answers, the risk of conducting the survey via internet, and the relatively low response rate (Fricker \& Mathias, 2001; Fox et al., 2003; Evans \& Mathur, 2005).

\section{References}

Baumgarten, J. (1978). Market value when there is no market. The Appraisal Journal, 56(1), 79-89.

Belfarge, E. (2001). Business value allocation in lodging valuation. The Appraisal Journal, 69(3), 277-282. 
Beuselinck, C., Manigart, S. (2007). Financial reporting quality in private equity backed entities: the impact of ownership concentration. Small Business Economics, 29(3), 261-274. doi:10.1007/s11187-006-9022-1.

Casta, J.F., \& Colasse, B. (Eds.). (2001). Juste valeur - enjeux techniques et politiques. Paris: Ed. Economica.

Cohen, V., \& Galiniene, B. (2013). Evaluation of commercial property market maturity: a case of Lithuania. International Journal of Strategic Property Management, 18(2), 151-162. doi:10. 3846/1648715X.2014.925007.

Deaconu, A., \& Buiga, A. (2010). Analysis of the convergence degree between the accounting and the valuation standards concerning fair value. Journal of Property Investment and Finance, 28(5), 365-384. doi:10.1108/14635781011069972.

Evans, J.R., Mathur, A. (2005). The value of online surveys. Internet Research, 15(2), 195-219. doi:10.1108/10662240510590360.

Fanning, S.F., Blazejack, J.A., Mann, G.R. (2011). Price versus fundamentals - from bubbles to distressed markets. The Appraisal Journal, 79(2), 143-154.

Fisher, D.J., Kinnard, N.W. (1990). The business enterprise value component of operating properties. Journal of Property Tax Management, 2(1), 19-27. doi:10.1007/978-14419-8953-6_15.

Fisher, D.J., \& Kinnard, N.W. (2001). The business enterprise value component of operating properties. In C.D. Lennhoff, A business enterprise value antology. Chicago: Appraisal Institute.

Fisher, D.J., Lentz, H.G. (1990). Business enterprise value in shopping malls: an empirical test. Journal of Real Estate Research, 5(1), 167-175.

Fishman, J.E., Pratt, S.P., \& Morisson, W.J. (2007). Standards of value. Theory and applications. London: John Wiley \& Sons.

Fox, J., Murray, C., Warm, A. (2003). Conducting research using web-based questionnaires: practical, methodological and ethical considerations. International Journal of Social Research Methodology, 6(2), 167-180. doi:10.1080/13645570210142883.

Fricker, R.D., \& Mathias, S. (2002). Advantages and disadvantages of Internet research surveys: Evidence from the literature. Field Methods, 14(4), 347-367. doi:10.1177/152582202237725.
Gélard, G. (2002). L'IASB 18 mois après. Revue Française de comptabilité, 348.

Gottdiener, N. (2008). Four keys to better asset valuations. American Banker, 173(114), 11.

Harper, D. (2008). Valuation of hotels for investors. Estate Gazette.

Hendriks, D. (2005). Apportionment in property valuation: should we separate the inseparable? Journal of Property Investment \& Finance, 23(5), 455-470. doi:10.1108/14635780510616043.

Hitz, J.M. (2007). The decision usefulness of fair value accounting - a theoretical perspective. European Accounting Review, 16(2), 323-362. doi:10.1080/09638180701390974.

Hrdý, M., Šimek, B. (2012). Valuation of the company in financial distress. E\&M Ekonomie a Management, 15(4), 121-133.

International Accounting Standards Board (IASB). (2013). International Financial Reporting Standards. IFRS 13, ed. 2013, Retrieved March 9, 2014, from http://eifrs.ifrs. org/eifrs/bnstandards/en/2013/ifrs13.pdf.

International Valuation Standards Council (IVSC). (2011). International Valuation Standards, ed. 2011. Retrieved March 9, 2014, from: http://www.ivsc.org/library.

Kucharska-Stasiak, E., Zelazowski, K. (2006). Implementation of international valuation standards in an emerging market. The Valuation Journal, 1, 36-54.

Mansfield, J.R., Royston, P.J. (2007). Aspects of valuation practice in Central and Eastern European economies. Property Management, 25(2), 150-163. doi:10.1108/02637470710741515.

Mard, M.J. (2009). Valuation: what's it worth. The Licensing Journal, June/July, 46-48.

Matonis, S., DeRango, D. (1993). The determination of hotel value components for ad valorem tax assessment. The Appraisal Journal, 61(3), 163-171.

Rérolle, J.F. (2008). The fair value debate: from accounting utopia to financial realism. Revue Trimestrielle de Droit Financier, 4, 1-12.

Ronen, J. (2008). To fair value or not to fair value: a broader perspective. ABACUS, 44(2), 181-208. doi:10.1111/j.1467-6281.2008.00257.x.

Staubus, G.J. (2008). The decision-usefulness theory of accounting: a limited history (New works in accounting history). New York: Garland Publishing.

Whittington, G. (2008). Fair value and the IASB/FASB conceptual framework project: an alternative view. ABACUS, 44(2), 139-168. doi:10.1111/j.1467-6281.2008.00255.x. 
Prof. Adela Deaconu, Ph.D. Babes-Bolyai University, Cluj-Napoca Faculty of Economics and Business Administration Department of Accounting and Audit adela.deaconu@econ.ubbcluj.ro

Ing. Sorana Crisan, Ph.D.

Babes-Bolyai University, Cluj-Napoca

KPMG Romania branch soranastanciu@yahoo.com
Assoc. Prof. Anuta Buiga, Ph.D. Babes-Bolyai University, Cluj-Napoca Faculty of Economics and Business Administration Department of Statistics Prognosis Mathematics anuta.buiga@econ.ubbcluj.ro 


\section{Appendix 1: Interview instrument administered to valuers}

Part 1 Characteristics of the activity of valuers

1. Practical experience

a) Less than 2 years; b) Between 2 and 5 years; c) Over 5 years.

2. Qualifications in valuation activity (multiple responses)

a) Real estate; b) Business, intangibles, goodwill; c) Plant \& equipment; d) Financial assets.

3. Weight of financial reporting valuations in the total volume of activities undertaken

a) Les than $10 \%$; b) Between 10 and 25\%; c) Between 25 and $40 \%$; d) Over $40 \%$

4. Frequency of valuations for companies with patrimony of different sizes (multiple responses)? (Low) 1 ...................2................................... 4 (High)

a) Consistent patrimony, nationally or regionally spread; b) Medium patrimony (maximum 2-3 sites or approximately 20 buildings with associated equipment); c) Low patrimony (only one site with maximum 5 to 10 buildings); d) Insignificant patrimony (one site with 1 to 3 buildings)

5. Categories of fixed assets most frequently valuated for financial reporting purposes (multiple responses)

(Low) 1 . 2. 3. .4 (High)

a) Land; b) Buildings; c) Plant \& equipment; d) Other (please describe)

6. Valuation approaches most frequently used for each category of fixed assets?

(Low) 1 . 2 . ... .4 (High)

6.1. Land: a) Market approach; b) Income approach; c) Cost approach

6.2. Buildings: a) Market approach; b) Income approach; c) Cost approach

6.3. Plant \& equipment: a) Market approach; b) Income approach; c) Cost approach

Part 2 Perceptions on the process of value allocation

7. Approaches applied in the case of the complex property (several types of fixed assets, for example land + buildings or land + buildings + associated equipment):

a) Estimate the value of the property as a whole, then allocate the value to each component of the property and disclose this in the valuation report; b) Estimate the value directly for each component; c) Estimate the value of the property as a whole and disclose this in the valuation report, while leaving the value allocation at the will of the beneficiary; d) Other (please specify)

8. Methods of value allocation to each component, in the case of property composed of land and buildings, when market or income approaches are used for valuation:

a) Deduct the market value of the land (estimated separately) from the total estimated value in order to obtain the fair value of the buildings; b) Deduct the net replacement cost of the buildings (estimated separately) from the total estimated value in order to obtain the fair value of the land; c) Other (please specify)

9. Methods of value allocation to each component, in the case of property composed of several buildings (including specialized property):

a) Value allocation using one key (pro rata); b) Deduct the value of the buildings that was possible to the estimated separately by using a classical valuation approach, and allocate the rest of the value to the remaining buildings by using pro rata; $c$ ) Other (please specify)

10. Value allocation keys used

(Low) 1 2. ......... 4. .5 (High)

a) Gross book value ; b) Net book value (deduced depreciation); c) Gross replacement cost; d) Net replacement cost; e) Other (please specify) 


\title{
Abstract
}

\section{VALUE ALLOCATION - CONTRIBUTION AND RISK TO THE RELIABILITY OF FINANCIAL REPORTING}

\author{
Adela Deaconu, Sorana Crisan, Anuta Buiga
}

Our study argues in favor of the reliability of fair value estimates for correct decision making by the stakeholders of the financial reporting market. The analysis is singularized to emergent contexts, as the Romanian market is the case study, and it is focused on the process of value allocation between the components of a group of assets. Having an application on fixed assets, the paper shows how fair value estimation is critical and implies risks on such an atypical market. The process of value allocation may bring a high level of arbitrariness to fair value accounting, this being crucial to apply correctly the valuation methodology in relation to the nature of the asset and market information available, and the selection of the allocation keys. The empirics of our study show a consistent expertise of Romanian valuators, as the most frequently used method for value allocation is the deduction of the value of those assets that was estimated based on the market approach, and not the values that were estimated based on the cost or income approach. Other findings show the frequent use of replacement cost, gross or net, to the detriment of book value, a very important aspect for an emergent market, even more so as revaluation in Romania does not guarantee that dedicated valuation methodology was used. These results are all the more important as land and buildings were the majority of fixed assets valuated, with the highest values as a result of the real estate bubble prior to the financial crisis, and with an essential role in the activity of the companies.

Key Words: Value allocation, financial reporting, international valuation standards, international financial reporting standards, fair value, real estate, credibility.

JEL Classification: M21, G32.

DOI: 10.15240/tul/001/2016-2-007 